\title{
THE RANKING OF THE WESTERN BALKAN COUNTRIES ACCORDING TO THE DEGREE OF GLOBALIZATION
}

\section{Assoc. Prof. Dr. Goran ZENDELOVSKI}

University of "Ss. Cyril and Methodius", Faculty of Philosophy, zendelovski@fzf.ukim.edu.mk

\section{Article history:}

Submission 1 September 2021

Revision 10 October 2021

Accepted 24 November 2021

Available online 31 December 2021

Keywords:

Variables,

Rating,

Indexes,

Globalization,

Western Balkans.

DOI:

https://doi.org/10.32936/pssj.v5i3.274

\begin{abstract}
A b s t r a t
Globalization does not have the same impact on countries, it acts differently in countries with different levels of political, economic, social and technological development. Its unequal distribution by region, country or community confirms that it is a complex and deeply asymmetric process. It is confirmed by numerous theories and debates that only explained and defined the phenomenon, but paid little attention to the complexity of globalization and measuring its extent. Empirical indicators can be used to measure the differences between the national and the international in different domains. In this way, it is possible to see to what extent the countries are globalized, i.e., to see the strong influence of globalization processes on the overall state of society. That is why a large number of countries try to use the processes of globalization to promote national interests and improve their position in international relations. Therefore, the analysis of the indexes of globalization will help us to understand with which components of national power the countries dominate on the regional and global scene.

The focus of the research is on the analysis of several globalization indexes that include the countries of the Western Balkan. Namely, the degree of globalization of countries is empirically analyzed through the prism of several different indicators that are constructed to measure the overall index of globalization, as well as to measure the political, economic and social dimension of globalization. The inclusion of a larger number of variables enables a more objective and accurate ranking of countries.

As the results of the globalization rating of the Western Balkan countries show, it is concluded that the processes of globalization greatly contribute to strengthening and improving cooperation between countries, intensify interdependence, affect Euro-Atlantic integration processes, stimulate economic growth and improve the situation in societies. However, according to the elaborated data, these countries are still in the phase of adjustment or "maturation", therefore, they are in the category of partially globalized countries.
\end{abstract}

\section{Introduction}

The discourse of globalization is based on theories that provide certain explanations and definitions of the phenomenon, but the complexity arises when globalization should be reduced to empirical indicators. For the first time, in the journal Foreign Policy, the title "Measuring Globalization" appeared, emphasizing that "Everyone talks about globalization, but no one has tried to measure its extent, at least not until now" (Foreign Policy, 2001: 56-65). Hence, in the mentioned text, indicators that contribute to and encourage integration are taken into account, and they are: cross-border personal contacts, international telephone calls, international postal exchange, the number of users of World Wide Web, foreign direct investments, trade, participation in international peacekeeping missions, etc. In fact, the empirical indicators are an attempt to give a "picture" of the differences between the national and the international, and which in fact are the main forces that show the degree of globalization.

At the same time, there are no clearly defined rules according to which countries should be governed, on the contrary, there is a word for "manipulation of variables", so that one indicator of the degree of globalization applies to one country, but not to another. 
Therefore, due to the complexity of globalization, in many cases misdiagnosis is given, because it is not a single process but a set of processes that operate simultaneously and unevenly on several levels and in different dimensions (Steger, 2003). This implies the need for detailed identification, research and assessment of the processes of globalization in each domain, while not going beyond the set framework of its functioning and realization. But let's see who and how much is globalized, to whose detriment or for what benefit, who globalizes who and under what conditions?

\section{How is the Extent of Globalization Measured?}

There are several renowned indexes of globalization, which give a picture of the rating of countries and developments in this segment, these indexes are developed by the Center for Study of Globalization and Regionalization - CSGR, A.T. Kearney and the Swiss Institute of Economics - KOF (Konjunkturforschungsstelle - KOF). Their results for the globalization of the countries are based on indicators that are categorized into three groups: economic, political and social aspects of globalization. However, some of the above indexes have certain shortcomings that relate to the way of selecting the variables that "distort" the picture and show it in a non-objective way the degree of globalization of the countries.

The Center for the Study of Globalization and Regionalization (CPGR) was established in 1997 and is the largest academic center in Europe dealing with this issue. CPGR research focuses on political economy, especially on the connection between global and regional aspects and on debates related to contemporary politics (Lockwood \& Redoano, 2006). However, according to the CPGR, the most exposed countries are from Western Europe, which are dominant according to the degree of globalization especially in the past three decades. A huge drawback is that there is no relevant data on the globalization of the countries of the Western Balkan.

The Globalization Index according to A.T. Kearney (which is the leading global company for management and consulting services in more than 40 countries in the world and which cooperates with more than $2 / 3$ of the largest companies in the world according to the Fortune Global 500), includes 62 countries that account for $96 \%$ of world GDP and make up $84 \%$ of the world's population. The index is based on 14 variables grouped into four categories: economic integration, (free trade and foreign direct investment), personal contact, (international travel and tourism, international telephone traffic, people transfer and etc.), technological connectivity, (internet users) and political engagement, (membership in international organizations, personnel and financial contributions in UN peacekeeping operations, international ratified agreements, etc.) (Foreign Policy, 2009).

The shortcomings of the index are that a small number of countries are covered and the dominance of the Western European countries, which are among the top ten in terms of rank, is preserved. At the same time, countries such as Belgium (which according to other indexes is one of the most globalized countries in the world) are not taken into account, nor are critical countries such as Afghanistan, Iraq and other countries represented in order to avoid the connection of globalization with terrorism, although there are unsubstantiated theories that are confirmed by the globalization index, that more globalized countries are less vulnerable to terrorist attacks than non-globalized states (Foreign Policy, 2005: 56). In addition, we consider that the authors of this index have tried the USA, Australia and New Zealand to bring them closer to the European countries, which does not cooperate with the real situation. Similar to the previous index of globalization, this index does not cover most of the Western Balkan countries.

Unlike previous indexes, the Globalization Index of the Swiss Institute of Economics - KOF (whose economic research dates back to before the Second World War) is more representative as it covers more than 200 countries and territories, and a large number of variables that rank countries more objectively and accurately are included (Dreher, 2006; Dreher, Noel \& Pim, 2008). The Globalization Index is based on 43 individual variables, which are aggregated to a de facto and a de jure index of three dimensions (economic, social and political globalization), five sub-dimensions (trade, financial, interpersonal, informational and cultural globalization), and one total index (Gygli, Florian, Niklas \& Jan-Egbert, 2019).

Economic globalization is measured by two categories, i.e. sub dimensions. The first category is trade globalization, i.e. consideration of economic globalization through trade, tariffs, taxes and trade agreements. The second category refers to financial globalization, which is measured by foreign direct investment, international debt, international income payments, international reserves, international investment agreements and the restrictions that countries take on in order to protect their economies from competing countries.

Social globalization is presented in three categories. The first is interpersonal globalization, which covers personal contacts, and refers to the direct interactions between people living in different countries. The second category is informational globalization, which includes variables related to the flow of information and ideas, television and internet access, high technology exports, 
press freedom, etc. The third category presents cultural globalization, which is measured by the number of McDonald's restaurants and Ikea stores, trade in cultural goods and personal services, gender parity and civil liberties, which for many are synonymous with globalization with Western prominence.

Political globalization is measured by the achieved political cooperation between countries. That is, the degree of political globalization is measured by the number of accredited embassies and high representatives, membership in international organizations and participation in UN peacekeeping missions, as well as the number of ratified agreements between two or more states (Dreher, 2006).

According to the methodological approach of the KOF Globalization Index, the changes of globalization are followed with the help of several variables for a larger number of countries and for a longer period of time. In doing so, relevant sources of organizations and institutions are used, such as the World Bank, the International Monetary Fund, the United Nations, the CIA World Factbook and others. The authors of this index of globalization have made a balance between the variables, i.e. equal representation of the same. The focus is on the economic and social aspects of globalization, taking into account a smaller number of variables for measuring the political aspects of globalization. There are other shortcomings, and they refer to the fact that some indicators, (for example, the economic ones), are more valid than the others, which gives them an advantage in some countries in relation to others. On the other hand, there is a lack of variables that measure the essential, economic and social aspects related to poverty, inequality, social inclusion and living standards. However, unlike other indexes, the KOF Globalization Index provides a comprehensive statistical analysis of the globalization of countries.

In general, all globalization indexes are dominated by the countries of Western Europe and North America, which were and still are the most globalized countries in the world for the period from 1980 to 2020 . At the bottom are mainly the poor countries located in the southern hemisphere of the globe in regions such as Sub-Saharan Africa, Latin America and the Caribbean, the Middle East and North Africa. This is another confirmation that modern globalization is an unequal process that mainly benefits the highly developed countries, while other countries and regions bypass them. The old-new leaders of globalization, the United States, the European leaders France and Germany, the most developed Asian country, Japan, and the BRICS countries (Brazil, Russia, India, China, and South Africa), as well as some Arab countries, are far from the required level they are less globalized than some countries that do not belong to the First World. There are doubts about the results in terms of how some smaller and less developed countries are in a higher position than the states that are considered world powers in the field of economy, politics, security and technology.

\section{The Degree of Globalization of the Western}

\section{Balkan Countries}

Until the beginning of the 21 st century, the countries of the Western Balkan were facing unfortunate developments, starting with the events that led to the disintegration of the former SFRY, where several wars were being fought, the constant political pressures, economic blockades, refugee crises, genocides and conflicts that have contributed to this region being marginalized by world events related to globalization. It took a long time for the countries of the Western Balkan to adapt and fit into global trends. The road that these countries took was the construction of a new system different from the already existing one. The order of political, economic, security - military and cultural factors determined the manner and speed of progress towards globalization, on which the future development and prosperity of the countries in this region depended.

However, with the gradual overcoming of the crisis situations and with the permanent assumption of obligations and fulfillment of the duties at the international level, most of the Balkan countries managed to fit in, primarily in the course of regionalization, and later in the globalization one's processes. In doing so, it was easier for some countries to adapt to the processes of globalization unlike some others. The period of adaptation that countries had to go through in order to gain the status of globalized countries varied from several years to several decades. In the modern era of globalization, it depended on the country's capabilities and the speed of adaptation to the new changes.

As for the countries in this region, it can be noticed that in a relatively short period of their independence, they have succeeded in entering the globalization processes. The progress of countries in relation to globalization can be seen in Table 1, which shows the countries of the Western Balkan. 
Table 1. The degree of globalization of the Western Balkan countries for the period from 2010 to 2020.

\begin{tabular}{c|c|c|c|c|c|c}
\hline Country & $\mathbf{2 0 1 0}$ & $\mathbf{2 0 1 2}$ & $\mathbf{2 0 1 4}$ & $\mathbf{2 0 1 6}$ & $\mathbf{2 0 1 8}$ & $\mathbf{2 0 2 0}$ \\
\hline Croatia & 29 & 32 & 33 & 35 & 29 & 29 \\
\hline Serbia & 51 & 45 & 63 & 46 & 40 & 37 \\
\hline Bosnia and Herzegovina & 58 & 62 & 50 & 55 & 53 & 64 \\
\hline N.Macedonia & 65 & 71 & 74 & 93 & 54 & 61 \\
\hline Albania & 94 & 78 & 86 & 88 & 63 & 75 \\
\hline Montenegro & 198 & 43 & 49 & 59 & 57 & 57 \\
\hline Kosovo & $/$ & $/$ & $/$ & $/$ & $/$ & $/$ \\
\hline
\end{tabular}

Source: Dreher, 2006; Dreher, Noel \& Pim, 2008; Gygli, Florian, Niklas \& Jan-Egbert, 2019.

According to the report, the most globalized country from this region is Croatia, followed by Serbia, and the least globalized countries are Republic of North Macedonia and Albania, while for Kosovo there are no data on the degree of globalization. Of the countries, the highest progress was made by Montenegro, which jumped from 198th place in 2010 to 43rd position in 2012.

Despite the fact that most of the Western Balkan countries are members of NATO and are candidates for EU membership (except Croatia, which has been a member of the EU since 2013), there are still no indications as to whether Euro-Atlantic integration has contributed to the rapid progress and globalization of countries. For example, Serbia, which is not a member of NATO, (for the period from 2016 to 2020), is better ranked than Albania, Montenegro and Macedonia, which are members of the Alliance.
In general, in the past decade, not a single country from this region should be included in the 20 best globalized countries nor in the category of the 20 weakest globalized countries in the world.

As for the situation in the Republic of North Macedonia, it is concluded that the country has the best position in 2018 (54th place) out of a total of 209 countries in the world. According to the political, economic and social aspects of globalization, for the period from 2010 to 2020 , it is the weakest ranking according to the political parameters of globalization, while in the past five years it has the best rating according to the economic parameters. The situation is similar in Albania and Montenegro, which are best ranked according to economic indicators, and weakest according to political parameters.

Table 2. The degree of globalization of the Western Balkan countries according to the economic, social and political parameters of globalization.

\begin{tabular}{|c|c|c|c|c|c|c|c|c|c|}
\hline \multirow{2}{*}{ Country } & \multicolumn{3}{|c|}{2010} & \multicolumn{3}{|c|}{2015} & \multicolumn{3}{|c|}{2020} \\
\hline & $\begin{array}{c}\text { Economic } \\
\text { Globalization }\end{array}$ & $\begin{array}{c}\text { Social } \\
\text { Globalization }\end{array}$ & $\begin{array}{c}\text { Political } \\
\text { Globalization }\end{array}$ & $\begin{array}{c}\text { Economic } \\
\text { Globalization }\end{array}$ & $\begin{array}{c}\text { Social } \\
\text { Globalization }\end{array}$ & $\begin{array}{c}\text { Political } \\
\text { Globalization }\end{array}$ & $\begin{array}{c}\text { Economic } \\
\text { Globalization }\end{array}$ & $\begin{array}{c}\text { Social } \\
\text { Globalization }\end{array}$ & $\begin{array}{c}\text { Political } \\
\text { Globalization }\end{array}$ \\
\hline Croatia & 35 & 36 & 49 & 43 & 42 & 41 & 36 & 36 & 39 \\
\hline Serbia & 56 & 68 & 82 & 79 & 58 & 80 & 41 & 63 & 40 \\
\hline $\begin{array}{l}\text { Bosnia and } \\
\text { Herzegovina }\end{array}$ & 49 & 96 & 69 & 76 & 65 & 64 & 87 & 87 & 70 \\
\hline N.Macedonia & 62 & 52 & 141 & 57 & 67 & 143 & 49 & 97 & 86 \\
\hline Albania & 88 & 121 & 87 & 74 & 122 & 130 & 54 & 99 & 111 \\
\hline Montenegro & 182 & 109 & 208 & 33 & 72 & 95 & 28 & 56 & 126 \\
\hline Kosovo & I & I & I & I & I & I & I & I & I \\
\hline
\end{tabular}

Source: Dreher, 2006; Dreher, Noel \& Pim, 2008; Gygli, Florian, Niklas \& Jan-Egbert, 2019.

However, according to certain empirical indicators North Macedonia in the past was among the highly globalized countries in the world. For example, the World Bank Report (Doing Business 2008) states that the country in the category of implementing economic reforms was ranked 4th in competition with 175 countries. Therefore, in the category of starting a business in 2015, it was on the 3rd place, or in general, according to the economic indicators, it was ranked on the 30th place in competition with 189 world economies (World Bank, 2014).
In terms of information technology, or according to the Report on Information Technology for 2015, the Republic of North Macedonia is best ranked in terms of Internet use and its prevalence in the country, and it ranks 47th out of a total of 143 countries in the world. While, according to the number of Internet users from the total population in 2014 , it was on the $43 \mathrm{rd}$ place (Ministry of Information Society and Administration, 2015).

Over the past decade, the country has been most recognizable and globalized, with participation in missions led by international organizations. In the ISAF mission in Afghanistan, it is ranked 
among the top ten Allies. That is, according to NATO data (for the contribution of the Republic of North Macedonia to the ISAF mission), it (per capita) was ranked 4th, and was behind the highly developed western countries of the United States, the United Kingdom and Denmark (Ministry of Defense of the Republic of North Macedonia, 2010).

These dilemmas and oscillations in the rating show that the modern processes of globalization are unpredictable and quite risky, seen from the political, economic and social aspects, and have a deep impact on the overall general situation in the societies. This means that in a short period of time certain countries from the category of highly globalized countries can move to less globalized countries and vice versa. For example, Ireland was in second place in 2009 and fell to 11th position within a year. This does not mean that Ireland is less globalized, but that other countries have improved their globalization rating much faster. Also, Iceland, one of the most desirable places to live and with the best standard in 2011, experienced a financial collapse the following year and went bankrupt.

For some countries, the globalizing will be a difficult and complex task, almost an impossible mission, because some of them are still not politically and even less economically or information-technologically mature. This refers approximately to "how to get them to drive a Formula 1 car, when they rode donkeys until yesterday" (Friedman, 1999). Does this mean that the less able will not "taste the fruits" of globalization that have been harvested by developed countries for decades? At the same time, distinctions should be made between the strong and the weak countries, which will formulate their national economic, foreign and security policies accordingly and thus give an appropriate answer to the dynamics of globalization.

In the context of the text above, we will mention the events at regional and global level that contributed to the improvement or deterioration of the degree of globalization in a number of countries, but also in the countries of the Western Balkan, and refers to the following:

- The global financial recession of 2008 has drastically reflected on the political, economic and social situation of the countries of Europe and North America;

- Events such as the Arab Spring (2011), the crisis in Ukraine (2014), the migrant and refugee crisis (2015), the global pandemic with COVID-19 (2020) contributed to a series of changes;

- The enlargement of the EU and NATO with new member states contributed to the increase of the globalization rating of a group of countries, thus improving their economic, political, social and security status;

- The involvement of countries in international organizations (WTO, IMF, World Bank) and participation in missions led by the UN, NATO and the EU has contributed to increasing the degree of globalization of countries in relation to economic, political and security aspects. In doing so, the highly developed countries, which are the most represented in international organizations and bodies, have a huge advantage over the countries that are not members or have a less decisive role in them;

- Countries affected by armed conflict or under the auspices of international organizations (such as Bosnia and Herzegovina and Kosovo) are less likely to globalize, because the least globalized countries are those that come from conflict regions, as opposed to highly globalized countries that are a benchmark for peace and stability;

- Bilateral disputes between the countries of the Western Balkan affect Euro-Atlantic integration processes. Due to this, this region is becoming more remote, i.e., marginalizes from the processes of progress and represents a "barrel of gunpowder", a danger to regional stability (Zendelovski \& Nacev, 2014).

- Regional initiatives contribute to strengthening and improving cooperation between countries in many areas. For example, the regional initiative "Open Balkan" (formerly called "Mini Schengen") is an economic and political zone of Albania, N. Macedonia and Serbia, which aims to allow free cross-border flow of people, capital, goods and services from the three countries from 2023.

Empirical results also point to the fact that globalization does not have the same effect in many areas, it acts very differently, and it determines the countries' ability to engage. The relationship of subordination and superiority is recognized, as well as the international division in relation to the engagement of individual institutions and international organizations. Some authors are right when they say that only statistical comparisons are offered among the societies and on the basis of some indicators they are ranked, without giving a specific explanation. This means that the methodological approach analyses the countries only quantitatively, or superficially, without delving into the essence of globalization. Hence, there is a doubt that the prevailing processes of globalization are viewed only through indicators and statistical analyses. In the previously presented hierarchy, the 
global actors are underlined - the countries that manage globalization and in which the optimistic scenario for the concept of globalization reigns, while the second category consists of the countries that are only observers and consumers of the consequences of the actions of global actors (Gjurovska, 2007).

In fact, the entire globalization discourse is based unilaterally on democratic and economic-financial indicators, while the socioecological and those related to the state welfare are out of consideration (McGrew, 2008). This was evident in the ranking of the Western Balkan countries, which since independence have opted for the Western neoliberal democratic concept. This indicates that some are more involved in the processes than the others, and are due to different criteria and geographical aspects. As modern asymmetric globalization continues at this pace, the question is whether most of the developing countries, including the Western Balkans region, will "catch the last train" that leads to prosperity and well-being?

\section{Conclusions}

Measuring globalization with the help of empirical indicators is a very complex process in research. There is confusion about what constitutes a globalized country and a country at the forefront of globalization. These are two opposing categories for which there is no precise scientific explanation. We have identified a number of shortcomings and dilemmas about how globalization works. It is noted that it is not politically neutral, nor is it economically equally distributed, but that it is a series of processes that generate political and economic implications and serve the interests of the great powers.

The countries of the Western Balkan, which are in the category of small developing countries, can fit in and make significant progress in terms of globalization, as it will be easier to govern them than the larger countries. This group of developing countries have embraced the model of Western liberal democracy, are open to free trade and economic development, and some of them are integrated into Euro-Atlantic structures, thus gaining a higher position in international relations. We believe that globalization processes create conditions for the countries of the Western Balkan to move closer to the countries of the First World. Although the rapprochement process is very slow (more than a decade), these countries, as they gradually become globalized, will have the opportunity to be competitive in the global market and achieve a higher level of development and prosperity. Through regional integration, the countries of the Western Balkan will be able to globalize faster, because regionalization will strengthen the forces in the process of globalization and lead to multilateral cooperation and openness of national economies.
Although these countries have a similar model of governance, each of them autonomously fits into the political, economic, social and security trends, at the same time globalizing and becoming a credible actor in international relations. Empirical results show that globalization has not had an equal impact on the Western Balkan countries. Thus, some of the countries are best ranked according to economic parameters, and weakest according to political indicators and vice versa. According to the data of globalization indexes, we noticed that the globalization discourse is based mainly on economic and financial indicators, and less on political, social and environmental indicators. From the presented indexes, the most representative is the updated KOF Globalization Index, which covers a large number of countries and is based on 43 specific variables that measure different dimensions of globalization. The disadvantage of this index is that there are fewer indicators that measure the political aspects of globalization.

Hence, the recommendation is for future research to focus on greater representation of the more significant indicators that are a benchmark for globalization, and through which the consequences of the processes of globalization can be reexamined. Therefore, it should be possible to combine multiple indicators to measure different aspects of globalization in order to rank countries more objectively and accurately. In this way, we will get answers as to why globalization is happening faster in some countries and much slower in others.

However, it is wrong to think that globalization serves smaller countries as well as large countries, because only the power of the great powers continues to grow. Does this mean that globalization is a means of manipulation (conspiracy theory or ideology), in favour of the most developed countries that contribute to the territorial division of the world on the basis of capital values? "The content of the country" (resources at its disposal, population, geographical size, information technology, engagement in regional and international organizations), determines the distinctiveness of the country which plays a key role in development and prosperity. Thus, regardless of whether a country is much globalized or not, in a long time the large highly developed countries will "carry" the economic, political, technological and security burden.

\section{References}

1. Bhagwati, J. (2004). In Defense of Globalization. Oxford University Press Inc.

2. Center for the Study of Globalization and Regionalization. (2012, October 18). Introduction to the CSGR Globalization Index. [Online] Available at: 
https://warwick.ac.uk/fac/soc/pais/research/csgr/inde $\underline{x / \text { intro }}$

3. Dreher, A. (2006). Does Globalization Affect Growth? Evidence from a new Index of Globalization. Applied Economics, 38 (10), 1091-1110. https://doi.org/10.1080/00036840500392078

4. Dreher, A., Noel, G., \& Pim, M. (2008). Measuring Globalisation - Gauging its Consequences. Springer.

5. Friedman, T.L. (1999). The lexus and the olive tree. Farrar Straus Giroux.

6. Gjurovska, M. (2007). Socioloskite aspekti na globalizacijata. Godisen Zbornik, 60, 83-100.

7. Gygli, S., Florian, H., Niklas, P., \& Jan-Egbert, S. (2019). The KOF Globalisation Index - Revisited. Review of International Organizations, 14(3), 543574. https://doi.org/10.1007/s11558-019-09344-2

8. Haelg, F. (2020). The KOF Globalisation Index-A Multidimensional Approach to Globalisation. Jahrbücher für Nationalökonomie und Statistik, 240(5), 691-696. https://doi.org/10.1515/jbnst-20190045

9. How the Index is Calculated? (2009, October 29). Foreign Policy. [Online] Available at: https://foreignpolicy.com/2009/10/29/how-the-indexis-calculated/

10. Kearney, A.T. (2018). 2018 Global Cities Report. [Online] Available at: https://www.kearney.com/global-cities/2018

11. KOF Globalisation Index. Retrieved September 17, 2021, from: https://kof.ethz.ch/en/forecasts-andindicators/indicators/kof-globalisation-index.html

12. Kołodko, G. W. (2002). Globalizacija i perspektivy razvitija postsocialističeskich stran. EGU.

13. Martens, P.,Caselli, M., De Lombaerde, P., Figge, L., \& Scholte, J. A. (2015).New directions in globalization indices. Globalizations, August, 1-12.

14. Lockwood, B., \& Redoano, M. (2006). The CSGR Globalization Index: An Introductory Guide. Working Paper,155(04). Available at: https://warwick.ac.uk/fac/soc/pais/research/csgr/inde x /download/

15. McGrew, A. (2008). Globalization and global politics In J.Baylis, S.Smith \& P.Owens (Eds.), The Globalization of World Politics: An Introduction to International Relations (pp. 14-33).Oxford University Press.

16. Measuring Globalization. (2001, January). Foreign Policy, 56-65.

17. Ministry of Defence of Republic of North Macedonia. (2010). Pridonesot na Republika Makedonija kon globalnata bezbednost, mir i stabilnost. [Online] Available

at:

https://www.mod.gov.mk/\%d0\%bf\%d1\%83\%d0\%b1 $\% \mathrm{~d} 0 \% \mathrm{bb} \% \mathrm{~d} 0 \% \mathrm{~b} 8 \% \mathrm{~d} 0 \% \mathrm{ba} \% \mathrm{~d} 0 \% 20 \% \mathrm{~b} 0 \% \mathrm{~d} 1 \% 86 \% \mathrm{~d}$ $0 \% 20 \% \mathrm{~b} 8 \% \mathrm{~d} 0 \% \mathrm{~b} 8$

18. Ministry of Information Society and Administration of Republic of North Macedonia. (2015). Makedonija napreduva za 10 pozicii na svetskata informaticka mapa. [Online] Available at: https://mioa.gov.mk/?q=mk

19. Nye, J.S., \& Keohane, R. O. (2000). Governance in a Globalizing World, Introduction. Brookings Institution Press.

20. Potrafke, N. (2015). The Evidence on Globalisation. The World Economy, 38(3), 509-552.

21. Reinert, E.S. (2006). Globalna Ekonomija: Kako su bogati postali bogati i zasto siromasni postaju siromasniji. Cigoja stampa.

22. Scholte, J.A. (2005). Globalization. A Critical Introduction (2nd ed.). Palgrave Macmillan.

23. Scholte, J.A. (2008). Defining globalization. The World Economy, 13 (11), 1471-1502.

24. Steger, M.L. (2003). Globalization - A Very Short Introduction. Oxford University Press.

25. The Royal Institute of International Affairs and The National Intelligence Council. (2005). Globalization and Future Architectures: Mapping the Global Future 2000 Project. [Online] Available at: https://www.dni.gov/files/documents/Global\%20Tre nds Mapping\%20the\%20Global\%20Future\%202020 \%20Project.pdf

26. Vujakovic, P. (2010). How to measure globalisation? A new globalisation index (NGI). Atlantic Economic Journal, 38(2), 237-237.

27. World Bank. (2014). Doing Business 2015: Going beyond Efficiency. [Online] Available at https://www.doingbusiness.org/content/dam/doingBu siness/media/Annual-Reports/English/DB15 -FullReport.pdf

28. World Bank. (2021). World development indicators (WDI). [Online] Available at: https://databank.worldbank.org/source/worlddevelopment-indicators

29. Zendelovski, G., \& Nacev, Z. (2014). Globalizacija, mirot i bezbednosta. Filozofski fakultet. 